\title{
Wavelengths From Thorium-Halide Lamps
}

\author{
William F. Meggers and Robert W. Stanley*
}

\begin{abstract}
The present system of international secondary standards of wavelength for spectroscopic measurements is based on interferometric determinations of wavelengths emitted at atmospheric pressure by an electric arc between iron electrodes. Because of the poor quality and uneven distribution of these iron standards they are not suitable for accurate measurement of wavelengths in the spectra of heavier elements, most of which are more complex and consist of much sharper lines than the standards. Quartz-tube lamps containing a small quantity of a thorium halide, when excited by microwaves, emit thousands of uniformly sharp and evenly distributed lines whose wavelengths, or positions in a spectrum, can be determined with about one-tenth the error of locating iron-arc lines. Preliminary values of 222 vacuum wavelengths emitted by a thorium-iodide lamp have been measured relative to 5462.2705 and 4047.7144 A emitted by a similar lamp containing mercury-198. Fabry-Perot interferometers with plate separations of 25,40 , or 50 millimeters were used with a stigmatic grating spectrograph in making these measurements. The thorium wavelengths range from 3288.7356 to $6991.5839 \mathrm{~A}$ in vacuum and from 3287.7885 to $6989.6562 \mathrm{~A}$ in standard air. The accuracy in relative value of 27 classified thorium lines is tested by means of the combination principle, which indicates that the average error is less than 1 part in 20 million.
\end{abstract}

\section{Introduction}

During the past half-century the wavelengths of hundreds of radiations from the iron are at atmospheric pressure have been measured with interferometers to serve as international standards of wavelength for spectroscopic measurements. The history and results of this activity were summarized in Wavelengths From Iron-Halide Lamps [1] ${ }^{1}$, in which it was shown that the accuracy of measurement could be increased by a factor of 2 or 3 if the iron lines were emitted by simple lamps containing a trace of iron halide excited, at low pressure and moderate temperature, by microwaves. But the iron are in air is still the main source of internationally adopted standard wavelengths.

The actual application of the adopted iron standards to wavelength measurements in various spectra is handicapped by two serious defects in the iron-arc spectrum. First, because of the high temperature $\left(6,300^{\circ} \mathrm{K}\right)$ of the iron are and the relatively small atomic number $(Z=26)$ and mass $(A=56)$ of the iron atom its spectral lines are excessively broadened on account of Doppler-Fizeau effect. Moreover, an electric arc between iron electrodes at atmospheric pressure produces lines of various kinds; strongly self-reversed lines involving low energy levels, diffuse lines involving high energy levels, and unstable lines of variable wavelength due to "pole effect." Second, the distribution of strong or similar lines in the arc spectrum of iron is such that no uniform spacing of wavelength standards is possible, and unduly large gaps between usable standards are unavoidable in certain spectral regions. Consequently many spectroscopists have expressed dissatisfaction with the international standards of wavelength emitted by the iron arc. Thus, Harrison [2] states that the wavelength precision of measurements in the MIT Wavelength Tables has been limited primarily by

* Present address, Purdue University, Lafayette, Ind

Figures in brackets indicate the literature references at the end of this paper. "the insufficiency of adequate wavelength standards in some spectra] regions, particularly of standard lines of suitable intensities." Likewise, Bovey [3] in giving a preliminary list of 6 -figure wavelengths of plutonium excited in a furnace complains that "A serious difficulty for accurate measurement has been the width of the iron-are lines, many of which are several times wider than the emission lines from ${ }^{4}$ furnace." Also Fred and Tomkins [4] in describing. the first two spectra of americium to 7 figures, announce that "Most of the uncertainty in the wavelengths is due to the poor quality of the standards, since the agreement in the hfs intervals shows that the line positions can be measured to another decimal place."

Logically the iron-are standards should have been used only for measuring atmospheric are and spark spectra of metals lighter than iron, because, other things equal, the heavier atoms emit sharper lines which cannot be measured accurately relative to standards that are broader and badly spaced. When the arc spectrum of cerium $(Z=58, \dot{A}=140)$ is photographed beside that of the standard iron are it is readily seen that all cerium lines are narrower than iron lines, and a comparison with thorium $(Z=90$, $A=232)$ or with uranium $(Z=92, A=238)$ is even more embarrassing for iron. This was observed by Harrison [5], who remarked that "In the extensive series of wavelength measurements made with the automatic comparator, which resulted in the publication of the Massachusetts Institute of Technology Wavelength Tables, the most serious limitation on precision was found to arise from the lack of satisfactory standard lines. Measurements on lines in such complex spectra as cerium and thorium, for example, showed much better internal consistency than did those on the iron standards themselves." To assist in remedying this situation, Harrison [5] cleverly contrived a complicated machine for the rapid direct determination of wavelengths from Fabry-Perot interferometer patterns. He called this machine the WINMAC 
(Wavelength interferometric measurement and computation), and in 1950 he reported [6] that "the WINMAC is now being readied for what is hoped will be an extensive series of wavelength determinations of intermediate wavelength standards in cerium, thorium, and other elements." Unfortunately this hope did not materialize. However, this is not seriously regretted now because in the meantime great improvements over the traditional ares and sparks at atmospheric pressure have been made in spectroscopic light sources.

The most simple, convenient, efficient, and economical type of spectroscopic light source is an evacuated tube of fused quartz enclosing a trace of gas, metal vapor, or volatile metallic compound excited by microwaves generated by vacuum-tube oscillators or by magnetrons. The prototype was the low pressure, water-cooled $\mathrm{Hg}^{198}$ lamp described by Meggers and Westfall [7], who also discovered that "clean-up" in such discharges varied inversely with frequency. In most laboratories magnetrons producing $2,450 \mathrm{Mc}$, or more, soon replaced vacuum-tube oscillators producing 100 to $300 \mathrm{Mc}$ for the excitation of these lamps. The preparation of similar lamps with other volatile metals was described by Zelikoff, Wyckoff, Aschenbrand, and Loomis [8], while Corliss, Bozman, and Westfall [9] demonstrated that such lamps can be made to emit the spectra of all metals that form volatile compounds. A precise procedure for the preparation of electrodeless discharge tubes containing very pure rare earths and highly radioactive elements has been described by Tomkins and Fred [10]. Compared with conventional ares and sparks, these lamps require a minimum amount of sample, which is enclosed and conserved. Also, they operate at relatively low temperature and pressure, and consequently emit spectral lines of greatly reduced width usually free of self-reversal. When operated with continuous wave power and moderate gas or vapor pressure, these lamps strongly favor the spectra of neutral atoms, but pulsed discharges and/or reduced pressures enhance the second and third spectra. Lamps viewed end-on when excited by a 100-watt magnetron emit spectra comparable in intensity to a 10 -ampere 220 volt d-c are, but with line widths much less than half as great. Bright, sharp lines are especially needed for the resolution of complex Zeeman patterns, or for the measurement of isotopic-spectroscopic effects. The development of these electrodeless lamps has thus greatly increased the range and precision of spectroscopic observations.

Now the accurate description and quantum interpretation of the spectra of rare-earth types of atoms and ions is still in a very unsatisfactory state, because of their extreme complexity and because pure samples have not been available in the past. The latter difficulty has recently been overcome either by efficient separation or by artificial preparation, but extreme complexity of the spectra remains as an obstacle to successful analysis. It is primarily for this reason that wavelengths must be measured with greater accuracy, and for this purpose reference standards of greater precision and better distribution than those from an iron arc are absolutely necessary.
Fortunately the simple electrodeless lamps referred to provide the means for obtaining a greatly improved system of standard wavelengths [11]. Lamps containing a trace of a thorium halide excited by microwaves emit approximately 20,000 lines of uniformly sharp character and even distribution between 2000 and $12000 \mathrm{~A}$. Since these lines are characteristic of heavy atoms and ions of even mass ( $Z=90, A=232$ ) they have relatively small DopplerFizeau widths, and are entirely free from hyperfine structure or isotope shifts. By imaging a thoriumhalide lamp inside a similar one containing $\mathrm{Hg}^{198}$ (or vice versa) both sources can be caused simultaneously to illuminate a Fabry-Perot interferometer and stigmatic spectrograph. From the interference patterns the wavelengths of thorium lines can then be determined to 8 figures relative to the previously determined values of the mercury lines. The purpose of this paper is to present preliminary results of such wavelength measurements for 222 radiations from thorium, covering slightly more than one octave of spectrum.

\section{Light Sources}

The thorium source used in this investigation was an electrodeless discharge tube containing a few milligrams of thorium iodide and pure helium gas at a pressure of $5 \mathrm{~mm}$ of $\mathrm{Hg}$ or less. The tube was prepared by C. H. Corliss in a manner previously described [9]. The tube blank is made of Vycor glass; it has a bore of approximately $5 \mathrm{~mm}$ and a length of $11.3 \mathrm{~cm}$. The discharge was excited at a frequency of $2,450 \mathrm{Mc}$ obtained from a commercial diathermy generator.

The thorium tube used throughout the investigation was chosen from among several that were made at the same time. After a warmup period of 30 to 60 sec, the tube would glow very brightly for approximately $3 \mathrm{~min}$. At the end of this time the thorium spectrum would weaken, and the discharge would be confined to a narrow filament near the center of the tube, indicating that the pressure in the tube had increased. The period of high intensity mentioned above was accompanied by a gradual movement of the thorium iodide deposit from the top to the bottom of the tube. As soon as the thorium spectrum began to weaken, the discharge tube was removed from its holder, cooled in water, and replaced in an inverted position with the thorium iodide deposit again at the top of the tube. For many of the photographs, this 3-min running time was sufficient. For longer exposures it was necessary to cool and invert the tube several times. This change could be made within 30 sec.

The primary standard on which the thorium measurements were based was a NBS-.Meggers $\mathrm{Hg}^{198}$ lamp [7], that contained $1 \mathrm{mg}$ of $\mathrm{Hg}^{198}$ and argon at a pressure of approximately $3 \mathrm{~mm}$ of $\mathrm{Hg}$. The mercury tube was excited by a second diathermy generator at the same frequency of $2,450 \mathrm{Mc}$. The H. ${ }^{198}$ source was cooled by an air stream from a small blower. 


\section{Experimental Method}

The optical arrangement was the same as that used by the authors in the previous investigation of iron wavelengths from an electrodeless tube [1]. For this reason, only a brief description will be given here. The Fabry-Perot interferometer consisted of aluminized quartz plates separated by 3 sets of invar pins either 25,40 , or $50 \mathrm{~mm}$ in length. Good interference fringes were also obtained with plate separation of $67.5 \mathrm{~mm}$, but lack of time did not permit the exploitation of the higher orders of interference.

The evacuated $\left(<10^{-4} \mathrm{~mm} \mathrm{Hg}\right)$ interferometer was mounted externally in parallel light. Both thorium and $\mathrm{Hg}^{198}$ lamps were placed on the optical axis but at right angles to it and parallel to the spectrograph slit, so that both sources were observed side-on. The $\mathrm{Hg}^{198}$ lamp was farther from the slit so that it could be imaged inside the thorium tube. From this point on, light from both lamps traveled the same path through condensing lens, interferometer, projection lens, and thence through the slit and spectrograph. The quartz-fluorite achromatic projection lens had the proper focal length $(50 \mathrm{~cm}$ or $100 \mathrm{~cm})$ to form six or more circular fringes on the spectrograph slit, which was $25 \mathrm{~mm}$ long and either 0.15 or $0.30 \mathrm{~mm}$ wide. Accuracy of measurement was thus favored by the large scale of the interference patterns and by a slit width that made the fringes approximate rectangles.

Dispersion in the horizontal direction was produced by a 15,000-line-per-inch concave grating in the Wadsworth mounting. The curvature of the plate holder was decreased so as to favor the horizontal focus and thus produce sharp images of the Fabry-Perot fringes from both lamps, simultaneously over as large a range as possible. This instrument was used to photograph diametral sections of interference patterns for waves between 4400 and $7000 \mathrm{~A}$, with a slit width of $0.30 \mathrm{~mm}$ and a reciprocal dispersion of $5 \mathrm{~A} / \mathrm{mm}$ in the first-order grating spectrum. Because of the higher density of lines in the ultraviolet spectrum of thorium, the region from 3275 to 4500 A was photographed in the second-order grating spectrum with a reciprocal dispersion of $2.45 \mathrm{~A} / \mathrm{mm}$ and slit width of $0.15 \mathrm{~mm}$. Under these conditions most of the measured interference patterns were free from overlaps of neighboring lines, but if many more thorium wavelengths are to be measured larger grating dispersion or smaller slit width will be necessary. In each wavelength range several spectrograms were made with different exposure times, and with slight mechanical-pressure changes in the interferometer spacing to alter the interference configurations or fractional orders for all spectral lines.

The interferometer plates were the same ones used previously for measurements of iron and mercury wavelengths $[1,12,13]$. The last series of measurements [13] suggested that the dispersion of phase change in the aluminum films was very small between 3300 and $6000 \mathrm{~A}$, so no corrections on account of phase change were applied to these thorium wave- lengths. No significant differences were found be tween results from the $25-, 40-$, and $50-\mathrm{mm}$ etalons.

All mercury lines that appeared with sufficient intensity were measured along with the thorium lines. The green (5462.2705 A) and violet (4047.7144 A) lines of $\mathrm{Hg}^{198}$ were chosen as standards respectively for the long- and short-wave interference spectrograms described above. The values of other $\mathrm{Hg}^{198}$ lines measured on these spectrograms agreed quite well with unpublished wavelengths [13], the greatest difference being $0.0002 \mathrm{~A}$. This supports our assumption that any possible corrections to these thorium preliminary wavelengths on account of dispersion of phase-change in the interferometer films are negligible.

The interferograms were measured at the National Bureau of Standards with the interference comparator designed by K. Burns [14], and at Purdue University with a comparator made by Carl Leiss. In order to measure as many thorium wavelengths as possible within a given time, it was found desirable to measure just 5 diameters of each interference pattern. As mentioned before [7], by measuring the diameters of 5 interference rings, the least-squares evaluation of the fractional order at the center may be made with a minimum of arithmetical computation because some of the steps are easily performed mentally. Even with this conservation of time and labor the thorium wavelengths presented in this paper required the bisection of more than 12,000 interference fringes and calculations for more than 1,200 individual patterns.

Another way to reduce the time and labor involved in interferometric comparisons of wavelengths is to begin with the largest orders of interference consistent with finding the correct integral order for each line. If grating measurements of wavelength are to be refined and replaced by interferometric values, the initial orders of interference should not be so great that errors in the grating values lead to wrong integral orders. For example, if a thorium wavelength near $5000 \mathrm{~A}$ is to be measured relative to $5462.2705 \mathrm{~A}$ of $\mathrm{Hg}^{198}$, the whole order of the thorium wavelength with a $25-\mathrm{mm}$ etalon will be about 100,000 , and the error in the grating value must be less than $\pm 0.02 \mathrm{~A}$ if it is to yield the correct integral order. We assumed that the available grating values of thorium wavelengths justified beginning the interferometric observations with a $25-\mathrm{mm}$ etalon and then testing these values with a $40-\mathrm{mm}$ etalon. If the integral orders of interference are in error because of too large errors in the grating values, the 25 - and 40 $\mathrm{mm}$ etalon values will differ radically, but if the integral orders are correct, the results will agree within a very small possible error of observation. This bold procedure saved much time and labor by eliminating interferometric observations with all smaller etalons which do not contribute anything to the accuracy attainable with the larger etalons.

Two independent sets of grating values of thorium wavelengths were available, one in the MIT Wavelength Tables [2] representing wavelengths emitted by a thorium arc, and the second representing unpublished wavelengths from thorium halide lamps measured by R. Zalubas in the National Bureau of 
TABLE 1. Thorium wavelengths: grating and interferometer values

\begin{tabular}{|c|c|c|c|c|c|}
\hline & $\lambda_{\text {air }}$ & $\lambda_{\mathrm{vac}}$ & $\lambda_{\mathrm{vac}}(25 \mathrm{~mm})$ & $\begin{array}{l}\text { Change } \\
\text { in order }\end{array}$ & $\lambda_{\mathrm{vac}}(40 \mathrm{~mm})$ \\
\hline $\begin{array}{l}\text { MIT } \\
\text { NBS } \ldots \ldots \ldots\end{array}$ & $\begin{array}{l}4165.813 \\
4165.782\end{array}$ & $\begin{array}{l}4166.987 \\
4166.956\end{array}$ & $\begin{array}{l}\text { 4166. } 9750 \\
4166.9403\end{array}$ & $+-\overline{1}$ & $\begin{array}{l}4166.9832 \\
4166.9403\end{array}$ \\
\hline $\begin{array}{l}\text { MIT } \\
\text { NBS } \ldots \ldots \ldots\end{array}$ & $\begin{array}{l}3869.639 \\
3869.665\end{array}$ & $\begin{array}{l}3870.736 \\
3870.762\end{array}$ & $\begin{array}{l}3870.7308 \\
3870.7606\end{array}$ & $-\overline{1}$ & $\begin{array}{l}3870.7416 \\
3870.7604\end{array}$ \\
\hline $\begin{array}{l}\text { MIT } \ldots \ldots \ldots \\
\text { NBS } \ldots \ldots \ldots\end{array}$ & $\begin{array}{l}3854.547 \\
3854.512\end{array}$ & $\begin{array}{l}3855.640 \\
3855.605\end{array}$ & $\begin{array}{l}3855.6333 \\
3855.6036\end{array}$ & $--\overline{1}$ & $\begin{array}{l}3855.6222 \\
3855.6035\end{array}$ \\
\hline $\begin{array}{l}\text { MIT } \ldots \ldots \\
\text { NBS } \ldots \ldots\end{array}$ & $\begin{array}{l}3421.189 \\
3421.215\end{array}$ & $\begin{array}{l}3422.170 \\
3422.196\end{array}$ & $\begin{array}{l}3422.1673 \\
3422.1908\end{array}$ & $-\cdots \overline{1}$ & $\begin{array}{l}3422.1618 \\
3422.1910\end{array}$ \\
\hline
\end{tabular}

Standards. Both sets were referred to the adopted secondary standards of wavelength obtained from the iron arc at atmospheric pressure. We gave preference to the MIT grating values because these were objectively measured and calculated by automatic machines [2], and therefore entirely free from human errors. This was a mistake; the only errors in integral orders of $25-\mathrm{mm}$ etalons occurred because of errors larger than $0.02 \mathrm{~A}$ in the MIT grating values as shown in table 1 . The first line shows in succession the MIT wavelength in air, its value in vacuum [15], and discordant results from 25-mm etalons and from 40-mm etalons. The second line gives similar data for NBS grating wavelengths, but the results from 25and $40-\mathrm{mm}$ etalons are in perfect agreement because the integral orders were corrected as indicated by the NBS grating values. The interferometric values for these four lines show that the MIT grating values have errors of $+0.047,-0.025,+0.036$, and $-0.021 \mathrm{~A}$, respectively, whereas the NBS errors are $+0.016,+0.001,+0.001$, and $+0.005 \mathrm{~A}$. No explanation of the large and erratic errors in the MIT grating values is offered, but this experience should be a warning that some 7 -figure MIT wavelengths may not be trustworthy beyond 5 figures.

\section{Results}

The thorium wavelengths obtained as a result of this investigation are presented in table 2 . Since the interferometer was evacuated and the separation of the interferometer plates was always expressed in terms of vacuum wavelengths of $\mathrm{Hg}^{198}$ standards, all the measured wavelengths of thorium are valid only in vacuum. Column 1 displays only that part of the vacuum wavelength that can be expressed in whole angstroms, the fraction that must be added to this is given in columns 2,3 , and 4, depending on whether it was measured respectively with $25-, 40-$, or 50-mm etalons. A figure in parentheses following each fraction shows the number of individual determinations. Column 5 contains the average preliminary vacuum wavelength resulting from all the observations. In column 6 the vacuum wavelenghts of column 5 are changed to values in standard air with the aid of Edlén's conversion table [15]. Column 7 quotes unpublished estimated relative intensities of thorium lines as given by Zalubas, and column 8 indicates the particular spectrum to which each wavelength belongs.

It is a common characteristic of all complex spectra that neutral atoms dominate the visible, and singlyionized atoms predominate in the ultraviolet. In these preliminary measurements of thorium wavelengths with Fabry-Perot etalons no difference in character could be observed between the Th I and Th II lines, and there is no reason to suspect that one category is more accurately measured than the other. Unfortunately none of the thorium wavelengths has been measured a sufficient number of times with any given etalon to compute a meaningful probable error or standard deviation. A considerable number of the wavelengths from a given etalon are limited to a single observation and a comparison of these with the over-all averages may give an impression of the uncertainty in individual observations.

Because of the lack of sufficient observational material to calculate probable errors of the thorium wavelengths, an attempt was made to test their relative values by means of the combination principle. Although the Thin spectrum has been extensively analyzed [16] no recurring wavenumber differences were found between ThII lines in table 2 . Somewhat better fortune was encountered with Th I lines. Even though the published analysis of ThI is extremely fragmentary [17] it is now being extended by Zalubas [18] who has reported that 27 of our interferometric values of Th I lines test the constancy of 4 wavenumber differences, viz., 2869.261, $3687.990,5563.143$, and $6362.396 \mathrm{~K}\left(=\mathrm{cm}^{-1}\right)$ between low-energy levels established for neutral thorium atoms. These are presented in table 3 as 14 pairs of vacuum wavelengths in $A$, and their reciprocals, or vacuum wavenumbers in $\mathrm{K}$. The mean deviation of the 14 differences from their arithmetical averages is $0.001_{2} \mathrm{~K}$, that is 1 part in about 20 million. The pairs numbered 2 and 3 account for two-thirds of the summed deviations; if these are ignored the remaining 12 exhibit an average departure of only $0.0005 \mathrm{~K}$, or 1 part in about 40 million, but this may be discounted as accidental.

The 222 wavelengths (3288.7356 to 6991.5839 A) of thorium radiations in table 2 are presented as a preliminary set of improved standard wavelengths for the measurement of highly-dispersed complex spectra. The average interval between these stand- 
TABLE 2. Wavelengths in thorium spectra

\begin{tabular}{|c|c|c|c|c|c|c|c|c|}
\hline 1 & 2 & 3 & 4 & 5 & 6 & 7 & 8 & \\
\hline \multirow{2}{*}{$\begin{array}{l}\text { Whole } \\
\text { angstrom }\end{array}$} & \multicolumn{3}{|c|}{ Fractional angstrom } & \multirow{2}{*}{ Vacuum } & \multirow{2}{*}{ Air } & \multirow{2}{*}{$\begin{array}{l}\text { Relative } \\
\text { intensity }\end{array}$} & \multirow{2}{*}{\multicolumn{2}{|c|}{ Spectrum }} \\
\hline & $25 \mathrm{~mm}$ (obs.) & $40 \mathrm{~mm}$ (obs.) & $50 \mathrm{~mm}$ (obs.) & & & & & \\
\hline $\begin{array}{l}6991 \\
6945 \\
6913 \\
6836 \\
6830\end{array}$ & $\begin{array}{l}5840(2) \\
5265(3) \\
1334(3) \\
8110(4) \\
9196(2)\end{array}$ & $\begin{array}{l}5839(3) \\
5266(3) \\
1338(3) \\
8114(2) \\
9205(1)\end{array}$ & $\begin{array}{l}5839(1) \\
5263(1) \\
1333(1) \\
8108(1) \\
9201(1)\end{array}$ & $\begin{array}{l}6991.5839 \\
6945.5265 \\
6913.1336 \\
6836.8110 \\
6830.9200\end{array}$ & $\begin{array}{l}6989.6562 \\
6943.6112 \\
6911.2264 \\
6834.9249 \\
6829.0355\end{array}$ & $\begin{array}{r}900 \\
600 \\
400 \\
75 \\
150\end{array}$ & $\begin{array}{l}\text { I } \\
\text { I } \\
\text { I } \\
\text { I } \\
\text { I }\end{array}$ & \\
\hline $\begin{array}{l}6758 \\
6729 \\
6680 \\
6664 \\
6660\end{array}$ & $\begin{array}{l}3179(3) \\
3153(2) \\
1088(4)\end{array}$ & $\begin{array}{l}3178(2) \\
3161(1) \\
5511(1) \\
1089(3) \\
5161 \quad(1)\end{array}$ & $\begin{array}{l}3176(1) \\
3162(1) \\
5522(1) \\
1094(1) \\
5161 \quad(1)\end{array}$ & $\begin{array}{l}6758.3178 \\
6729.3157 \\
6680.5516 \\
6664.1090 \\
6660.5161\end{array}$ & $\begin{array}{l}6756.4528 \\
6727.4585 \\
6678.7076 \\
6662.2694 \\
6658.6774\end{array}$ & $\begin{array}{r}250 \\
200 \\
30 \\
250 \\
50\end{array}$ & $\begin{array}{l}\text { I } \\
\text { I } \\
\text { I } \\
\text { I } \\
\text { I }\end{array}$ & \\
\hline $\begin{array}{l}6595 \\
6593 \\
6590 \\
6585 \\
6555\end{array}$ & $\begin{array}{l}7610(4) \\
3595(4) \\
7248(4) \\
9715(2)\end{array}$ & $\begin{array}{l}7610(3) \\
3059(1) \\
3600(2) \\
7254(3) \\
9710(4)\end{array}$ & $\begin{array}{l}7608(1) \\
3051(1) \\
3596(1) \\
7251(1) \\
9707(1)\end{array}$ & $\begin{array}{l}6595.7610 \\
6593.3055 \\
6590.3596 \\
6585.7251 \\
6555.9711\end{array}$ & $\begin{array}{l}6593.9397 \\
6591.4849 \\
6588.5398 \\
6583.9065 \\
6554.1605\end{array}$ & $\begin{array}{l}200 \\
100 \\
200 \\
200 \\
100\end{array}$ & $\begin{array}{l}\text { I } \\
\text { I } \\
\text { I } \\
\text { I } \\
\text { I }\end{array}$ & \\
\hline $\begin{array}{l}6533 \\
6492 \\
6459 \\
6415 \\
6413\end{array}$ & $\begin{array}{l}1468(5) \\
5317(2) \\
0675(4) \\
6717(4)\end{array}$ & $\begin{array}{l}1465(4) \\
5312(4) \\
0678(3) \\
3881(3) \\
6721 \quad(4)\end{array}$ & $\begin{array}{l}1466(1) \\
5313(1) \\
0680(1) \\
3876(1) \\
6719(1)\end{array}$ & $\begin{array}{l}6533.1467 \\
6492.5313 \\
6459.0677 \\
6415.3880 \\
6413.6719\end{array}$ & $\begin{array}{l}6531.3423 \\
6490.7378 \\
6457.2834 \\
6413.6152 \\
6411.8996\end{array}$ & $\begin{array}{l}400 \\
120 \\
500 \\
200 \\
250\end{array}$ & $\begin{array}{l}\text { I } \\
\text { I } \\
\text { I } \\
\text { I } \\
\text { I }\end{array}$ & \\
\hline $\begin{array}{l}6378 \\
6344 \\
6329 \\
6263 \\
6259\end{array}$ & $\begin{array}{l}6939(3) \\
6134(4) \\
0286(2) \\
1499(4) \\
1546(3)\end{array}$ & $\begin{array}{l}6940(4) \\
6143(4) \\
0285(4) \\
1493(4) \\
1546(3)\end{array}$ & $\begin{array}{l}6933(1) \\
6135(1) \\
0270(1) \\
1504(1) \\
1548(1)\end{array}$ & $\begin{array}{l}6378.6939 \\
6344.6138 \\
6329.0284 \\
6263.1496 \\
6259.1546\end{array}$ & $\begin{array}{l}6376.9310 \\
6342.8600 \\
6327.2788 \\
6261.4177 \\
6257.4237\end{array}$ & $\begin{array}{l}350 \\
300 \\
180 \\
180 \\
100\end{array}$ & $\begin{array}{l}\text { I } \\
\text { I } \\
\text { I } \\
\text { I } \\
\text { I }\end{array}$ & \\
\hline $\begin{array}{l}6226 \\
6208 \\
6193 \\
6184 \\
6153\end{array}$ & $\begin{array}{l}249^{\prime} i \quad(2) \\
9379 \quad(5) \\
3324(4) \\
6954(5)\end{array}$ & $\begin{array}{l}2494(4) \\
9380(4) \\
6188(1) \\
3331(4) \\
6962(3)\end{array}$ & $\begin{array}{l}2494(1) \\
9378(1) \\
6186(1) \\
3326(1) \\
6959(1)\end{array}$ & $\begin{array}{l}6226.2495 \\
6208.9379 \\
6193.6187 \\
6184.3327 \\
6153.6958\end{array}$ & $\begin{array}{l}6224.5275 \\
6207.2205 \\
6191.9054 \\
6182.6219 \\
6151.9932\end{array}$ & $\begin{array}{l}100 \\
160 \\
100 \\
400 \\
120\end{array}$ & $\begin{array}{l}\text { I } \\
\text { I } \\
\text { I } \\
\text { I } \\
\text { I }\end{array}$ & \\
\hline $\begin{array}{l}6104 \\
6089 \\
6087 \\
6050 \\
6039\end{array}$ & $\begin{array}{l}2838(2) \\
7161(2) \\
0592(5) \\
7258(2) \\
3696 \quad(5)\end{array}$ & $\begin{array}{l}2837(2) \\
7159(2) \\
0596(2) \\
7259(2) \\
3700 \quad(4)\end{array}$ & $\begin{array}{l}2849(1) \\
7160(1) \\
0586(1) \\
7259(1) \\
3696(1)\end{array}$ & $\begin{array}{l}6104.2839 \\
6089.7160 \\
6087.0592 \\
6050.7259 \\
6039.3697\end{array}$ & $\begin{array}{l}6102.5946 \\
6088.0306 \\
6085.3745 \\
6049.0510 \\
6037.6978\end{array}$ & $\begin{array}{r}90 \\
125 \\
100 \\
100 \\
140\end{array}$ & $\begin{array}{l}\text { I } \\
\text { I } \\
\text { I } \\
\text { I } \\
\text { I }\end{array}$ & \\
\hline $\begin{array}{l}6022 \\
6008 \\
5976 \\
5975 \\
5940\end{array}$ & $\begin{array}{l}7042(1) \\
7362(4) \\
7202(2) \\
3202(5) \\
4710(4)\end{array}$ & $\begin{array}{l}7038(2) \\
7361(4) \\
7208(4) \\
3196(4) \\
4708(4)\end{array}$ & $\begin{array}{l}7364(1) \\
7213(1) \\
3193(1) \\
4708(1)\end{array}$ & $\begin{array}{l}6022.7040 \\
6008.7362 \\
5976.7207 \\
5975.3199 \\
5940.4709\end{array}$ & $\begin{array}{l}6021.0362 \\
6007.0725 \\
5975.0656 \\
5973.6651 \\
5938.8255\end{array}$ & $\begin{array}{l}140 \\
180 \\
250 \\
250 \\
140\end{array}$ & $\begin{array}{l}\text { I } \\
\text { I } \\
\text { I } \\
\text { I }\end{array}$ & \\
\hline $\begin{array}{l}5887 \\
5854 \\
5805 \\
5792 \\
5791\end{array}$ & $\begin{array}{l}3325(1) \\
3043(4) \\
7508(5) \\
2686(5) \\
2494(3)\end{array}$ & $\begin{array}{l}3331(1) \\
3033(2) \\
7507 \quad(4) \\
2686(3) \\
2495 \quad(2)\end{array}$ & $\begin{array}{l}3329(1) \\
3053(1) \\
7509(1) \\
2683(1) \\
2492(1)\end{array}$ & $\begin{array}{l}5887.3329 \\
5854.3040 \\
5805.7508 \\
5792.2686 \\
5791.2494\end{array}$ & $\begin{array}{l}5885.7017 \\
5852.6817 \\
5804.1414 \\
5790.6629 \\
5789.6439\end{array}$ & $\begin{array}{r}120 \\
200 \\
300 \\
-200\end{array}$ & 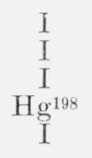 & \\
\hline $\begin{array}{l}5771 \\
5762 \\
5726 \\
5708 \\
5659\end{array}$ & $\begin{array}{l}1983(5) \\
1484(4) \\
9766(1) \\
6864(4) \\
\end{array}$ & $\begin{array}{l}1983(4) \\
1489(4) \\
9771(3) \\
6870(4) \\
4963(1)\end{array}$ & $\begin{array}{l}1980(1) \\
1489(1) \\
6872(1) \\
4958(1)\end{array}$ & $\begin{array}{l}5771.1983 \\
5762.1487 \\
5726.9770 \\
5708.6867 \\
5659.4960\end{array}$ & $\begin{array}{l}5769.5982 \\
5760.5510 \\
5725.3887 \\
5707.1033 \\
5657.9258\end{array}$ & $\begin{array}{l}600 \\
250 \\
200 \\
100\end{array}$ & $\begin{array}{l}\mathrm{Hg}_{\mathrm{I}}^{198} \\
\mathrm{I} \\
\mathrm{I}\end{array}$ & II \\
\hline $\begin{array}{l}5641 \\
5616 \\
5588 \\
5580 \\
5574\end{array}$ & $\begin{array}{l}3109 \\
8789(3) \\
5775(5) \\
9073(3) \\
9014(4)\end{array}$ & $\begin{array}{l}3122(3) \\
8790(4) \\
5780(5) \\
9080(4) \\
9015(4)\end{array}$ & $\begin{array}{l}3120(1) \\
5781(1) \\
9080(1) \\
9010(1)\end{array}$ & $\begin{array}{l}5641.3115 \\
5616.8790 \\
5588.5778 \\
5580.9077 \\
5574.9014\end{array}$ & $\begin{array}{l}5639.7461 \\
5615.3202 \\
5587.0265 \\
5579.3585 \\
5573.3538\end{array}$ & $\begin{array}{l}250 \\
350 \\
500 \\
300 \\
350\end{array}$ & $\begin{array}{l}\text { I } \\
\text { I } \\
\text { I } \\
\text { I }\end{array}$ & II \\
\hline $\begin{array}{l}5559 \\
5549 \\
5540 \\
5511 \\
5500\end{array}$ & $\begin{array}{l}8862(3) \\
7171(4) \\
8001(5) \\
5243(4) \\
7828(5)\end{array}$ & $\begin{array}{l}8862(4) \\
7169 \\
8000(3) \\
5247 \\
7831(5)\end{array}$ & $\begin{array}{l}8859(1) \\
7172(1) \\
7999(1) \\
5238(1) \\
7831(1)\end{array}$ & $\begin{array}{l}5559.8862 \\
5549.7170 \\
5540.8000 \\
5511.5244 \\
5500.7830\end{array}$ & $\begin{array}{l}5558.3426 \\
5548.1761 \\
5539.2615 \\
5509 \\
5199.2552\end{array}$ & $\begin{array}{l}400 \\
300 \\
400 \\
300 \\
250\end{array}$ & $\begin{array}{l}\text { I } \\
\text { I } \\
\text { I } \\
\text { I } \\
\text { I }\end{array}$ & \\
\hline
\end{tabular}


TABLE 2. Wavelengths in thorium spectra-Continued

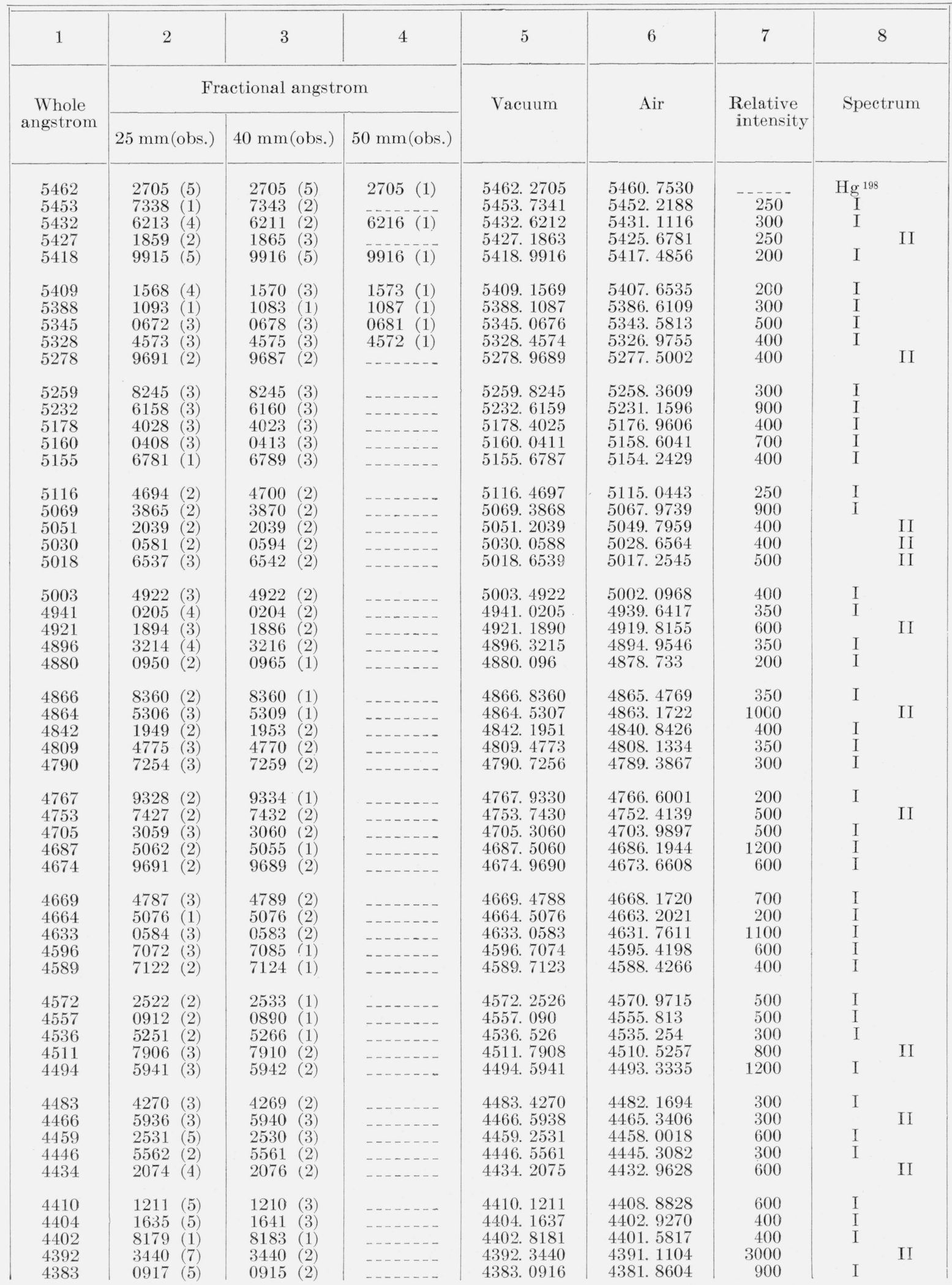


TABLE 2. Wavelengths in thorium spectra-Continued

\begin{tabular}{|c|c|c|c|c|c|c|c|c|}
\hline 1 & 2 & 3 & 4 & 5 & 6 & 7 & 8 & \\
\hline \multirow{2}{*}{$\begin{array}{l}\text { Whole } \\
\text { angstrom }\end{array}$} & \multicolumn{3}{|c|}{ Fractional angstrom } & \multirow{2}{*}{ Vacuum } & \multirow{2}{*}{ Air } & \multirow{2}{*}{$\begin{array}{l}\text { Relative } \\
\text { intensity }\end{array}$} & \multirow{2}{*}{\multicolumn{2}{|c|}{ Spectrum }} \\
\hline & $25 \mathrm{~mm}$ (obs.) & $40 \mathrm{~mm}$ (obs.) & $50 \mathrm{~mm}$ (obs.) & & & & & \\
\hline $\begin{array}{l}4379 \\
4375 \\
4367 \\
4359 \\
4343\end{array}$ & $\begin{array}{l}4069(5) \\
3535(2) \\
1572(5) \\
5624(4) \\
4765(4)\end{array}$ & $\begin{array}{ll}4072 & (2) \\
3538 & (1) \\
1575 & (2) \\
5624 & (3) \\
4760 & (2)\end{array}$ & 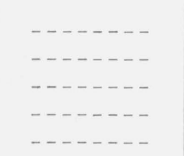 & $\begin{array}{l}4379.4070 \\
4375.3536 \\
4367.1573 \\
4359.5624 \\
4343.4763\end{array}$ & $\begin{array}{l}4378.1768 \\
4374.1244 \\
4365.9303 \\
4358.3374 \\
4342.2555\end{array}$ & $\begin{array}{r}500 \\
600 \\
600 \\
-300\end{array}$ & $\begin{array}{c}\mathrm{I} \\
\mathrm{I} \\
\mathrm{H} \mathrm{g}^{198} \\
\mathrm{I}\end{array}$ & \\
\hline $\begin{array}{l}4332 \\
4319 \\
4316 \\
4308 \\
4301\end{array}$ & $\begin{array}{ll}0620 & (3) \\
6302 & (1) \\
4681 & (3) \\
3878 & (3) \\
0490 & (3)\end{array}$ & $\begin{array}{l}0617(1) \\
6307(1) \\
4681(2) \\
3878(2) \\
0486(1)\end{array}$ & 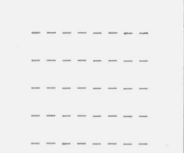 & $\begin{array}{l}\text { 4332. } 0619 \\
4319.6305 \\
4316.4681 \\
4308.3878 \\
4301.0489\end{array}$ & $\begin{array}{l}4330.8441 \\
4318.4160 \\
4315.2544 \\
4307.1763 \\
4299.8393\end{array}$ & $\begin{array}{l}300 \\
700 \\
400 \\
700 \\
600\end{array}$ & $\begin{array}{l}\text { I } \\
\text { I } \\
\text { I } \\
\text { I } \\
\text { I }\end{array}$ & \\
\hline $\begin{array}{l}4293 \\
4278 \\
4274 \\
4258 \\
4236\end{array}$ & $\begin{array}{l}0176(3) \\
5178(3) \\
5599(3) \\
6946(3) \\
6563(3)\end{array}$ & $\begin{array}{l}0178(2) \\
5181(2) \\
5603(2) \\
6941(2) \\
6560(1)\end{array}$ & 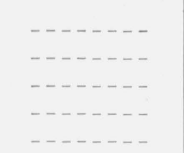 & $\begin{array}{l}4293.0177 \\
4278.5179 \\
4274.5600 \\
4258.6944 \\
4236.6562\end{array}$ & $\begin{array}{l}4291.8102 \\
4277.3142 \\
4273.3574 \\
4257.4959 \\
4235.4635\end{array}$ & $\begin{array}{r}400 \\
1200 \\
1000 \\
700 \\
600\end{array}$ & $\begin{array}{l}\text { I } \\
\text { I } \\
\text { I }\end{array}$ & $\begin{array}{l}\text { II } \\
\text { II }\end{array}$ \\
\hline $\begin{array}{l}4231 \\
4216 \\
4210 \\
4194 \\
4179\end{array}$ & $\begin{array}{ll}6183 & (3) \\
0152 & (2) \\
0766 & (3) \\
1981 & (3) \\
2375 & (3)\end{array}$ & $\begin{array}{l}6180(1) \\
0161(1) \\
0762(2) \\
1980(2) \\
2374 \quad(2)\end{array}$ & 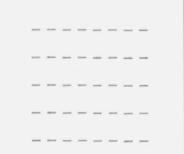 & $\begin{array}{l}\text { 4231. } 6182 \\
4216.0156 \\
4210.0764 \\
4194.1980 \\
4179.2374\end{array}$ & $\begin{array}{l}\text { 4230. } 4268 \\
4214.8283 \\
4208.8907 \\
4193.0165 \\
4178.0598\end{array}$ & $\begin{array}{r}600 \\
200 \\
3000 \\
900 \\
3000\end{array}$ & $\begin{array}{l}\text { I } \\
\text { I }\end{array}$ & II \\
\hline $\begin{array}{l}4166 \\
4159 \\
4151 \\
4133 \\
4128\end{array}$ & $\begin{array}{ll}9403 & (3) \\
7078 & (3) \\
1566 & (3) \\
9191 & (3) \\
5761 & (3)\end{array}$ & $\begin{array}{l}9403(2) \\
7074(2) \\
1570(2) \\
9191(1) \\
5759(2)\end{array}$ & 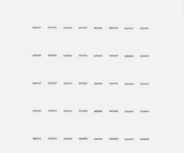 & $\begin{array}{l}4166.9403 \\
4159.7076 \\
4151.1568 \\
4133.9191 \\
4128.5760\end{array}$ & $\begin{array}{l}4165.7659 \\
4158.5351 \\
4149.9865 \\
4132.7534 \\
4127.4117\end{array}$ & $\begin{array}{r}1000 \\
800 \\
800 \\
600 \\
1400\end{array}$ & $\begin{array}{l}\text { I } \\
\text { I }\end{array}$ & $\begin{array}{l}\text { II } \\
\text { II }\end{array}$ \\
\hline $\begin{array}{l}4116 \\
4109 \\
4101 \\
4095 \\
4087\end{array}$ & $\begin{array}{l}9199(3) \\
5788(3) \\
4985(3) \\
9025(3) \\
6743(2)\end{array}$ & $\begin{array}{ll}9201 & (2) \\
5791 & (1) \\
4984 & (2) \\
9031 & (2) \\
6739 & (2)\end{array}$ & 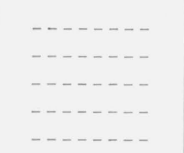 & $\begin{array}{l}4116.9200 \\
4109.5789 \\
4101.4984 \\
4095.9028 \\
4087.6741\end{array}$ & $\begin{array}{l}4115.7587 \\
4108.4195 \\
4100.3412 \\
4094.7470 \\
4086.5205\end{array}$ & $\begin{array}{r}800 \\
800 \\
1100 \\
1600 \\
1600\end{array}$ & I & $\begin{array}{l}\text { II } \\
\text { II }\end{array}$ \\
\hline $\begin{array}{l}4068 \\
4060 \\
4047 \\
4044 \\
4037\end{array}$ & $\begin{array}{ll}5993 & (3) \\
3990 & (3) \\
7144 & (3) \\
5366 & (3) \\
1880 & (3)\end{array}$ & $\begin{array}{ll}5992 & (2) \\
3991 & (2) \\
7144 & (2) \\
5371 & (2) \\
1878 & (2)\end{array}$ & 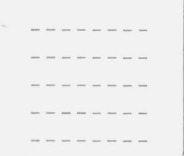 & $\begin{array}{l}4068.5993 \\
4060.3990 \\
4047.7144 \\
4044.5368 \\
4037.1879\end{array}$ & $\begin{array}{l}4067.4507 \\
4059.2525 \\
4046.5712 \\
4043.3945 \\
4036.0475\end{array}$ & $\begin{array}{r}400 \\
1000 \\
--\overline{800} \\
1800\end{array}$ & $\begin{array}{c}\mathrm{I} \\
\mathrm{I} \\
\mathrm{Hg} \\
\mathrm{I} \\
\mathrm{I}\end{array}$ & \\
\hline $\begin{array}{l}4020 \\
4013 \\
4009 \\
3995 \\
3981\end{array}$ & $\begin{array}{ll}2649 & (4) \\
6295 & (3) \\
3433 & (3) \\
6786 & (3) \\
2147 & (3)\end{array}$ & $\begin{array}{ll}2649 & (2) \\
6292 & (2) \\
3438 & (2) \\
6787 & (2) \\
2153 & (2)\end{array}$ & 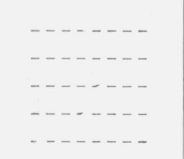 & $\begin{array}{l}4020.2649 \\
4013.6293 \\
4009.3435 \\
3995.6786 \\
3981.2150\end{array}$ & $\begin{array}{l}4019.1289 \\
4012.4950 \\
4008.2104 \\
3994.5490 \\
3980.0892\end{array}$ & $\begin{array}{l}4000 \\
2000 \\
1600 \\
1200 \\
1100\end{array}$ & $\begin{array}{l}\text { I } \\
\text { I } \\
\text { I } \\
\text { I }\end{array}$ & II \\
\hline $\begin{array}{l}3968 \\
3950 \\
3934 \\
3924 \\
3906\end{array}$ & $\begin{array}{l}5145(3) \\
0814(2) \\
0243(3) \\
9103(3) \\
2992(2)\end{array}$ & $\begin{array}{l}5142(2) \\
0810(1) \\
0243(1) \\
9106(1) \\
2926(1)\end{array}$ & 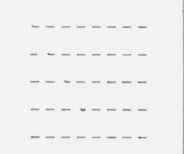 & $\begin{array}{l}\text { 3968. } 5144 \\
3950.0813 \\
3934.0243 \\
3924.9104 \\
\text { 3906. } 2924\end{array}$ & $\begin{array}{l}\text { 3967. } 3919 \\
3948.9636 \\
3932.9108 \\
3923.7993 \\
3905.1861\end{array}$ & $\begin{array}{r}2000 \\
1000 \\
1400 \\
400 \\
1500\end{array}$ & $\begin{array}{l}\mathrm{I} \\
\mathrm{I} \\
\mathrm{I} \\
\mathrm{I}\end{array}$ & II \\
\hline $\begin{array}{l}3870 \\
3864 \\
3855 \\
3843 \\
3840\end{array}$ & $\begin{array}{ll}7606 & (2) \\
5008 & (3) \\
6036 & (3) \\
0497 & (3) \\
7829 & (3)\end{array}$ & $\begin{array}{l}7604(2) \\
5011(2) \\
6035(2) \\
0499(2) \\
7837(2)\end{array}$ & 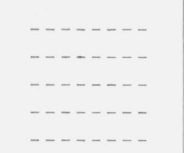 & $\begin{array}{l}3870.7605 \\
3864.5009 \\
3855.6036 \\
3843.0498 \\
3840.7833\end{array}$ & $\begin{array}{l}3869.6635 \\
3863.4055 \\
3854.5105 \\
3841.9600 \\
3839.6941\end{array}$ & $\begin{array}{r}600 \\
1200 \\
1200 \\
1200 \\
2500\end{array}$ & $\mathrm{I}$ & $\begin{array}{l}\text { II } \\
\text { II } \\
\text { II }\end{array}$ \\
\hline $\begin{array}{l}3829 \\
3819 \\
3814 \\
3804 \\
3786\end{array}$ & $\begin{array}{l}4707(3) \\
7691(1) \\
1497(3) \\
1545(3) \\
6748(1)\end{array}$ & $\begin{array}{l}4709(2) \\
7692(1) \\
1497(2) \\
1550(2) \\
6749(1)\end{array}$ & 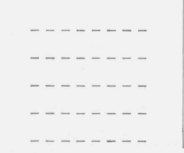 & $\begin{array}{l}3829.4708 \\
3819.7692 \\
3814.1497 \\
3804.1547 \\
3786.6749\end{array}$ & $\begin{array}{l}3828.3845 \\
3818.6855 \\
3813.0674 \\
3803.0750 \\
3785.5997\end{array}$ & $\begin{array}{r}3200 \\
500 \\
1200 \\
4000 \\
1000\end{array}$ & $\begin{array}{l}\mathrm{I} \\
\mathrm{I} \\
\mathrm{I}\end{array}$ & $\begin{array}{l}\text { II } \\
\text { II }\end{array}$ \\
\hline
\end{tabular}


TABLE 2. Wavelengths in thorium spectra-Continued

\begin{tabular}{|c|c|c|c|c|c|c|c|c|}
\hline 1 & 2 & 3 & 4 & 5 & 6 & 7 & 8 & \\
\hline \multirow{2}{*}{$\begin{array}{l}\text { Whole } \\
\text { angstrom }\end{array}$} & \multicolumn{3}{|c|}{ Fractional angstrom } & \multirow{2}{*}{ Vacuum } & \multirow{2}{*}{ Air } & \multirow{2}{*}{$\begin{array}{l}\text { Relative } \\
\text { intensity }\end{array}$} & \multirow{2}{*}{\multicolumn{2}{|c|}{ Spectrum }} \\
\hline & $25 \mathrm{~mm}$ (obs.) & $40 \mathrm{~mm}$ (obs.) & $50 \mathrm{~mm}$ (obs.) & & & & & \\
\hline $\begin{array}{l}3782 \\
3772 \\
3764 \\
3753 \\
3743\end{array}$ & $\begin{array}{ll}0398 & (1) \\
4418 & (3) \\
0037 & (3) \\
6349 & (3) \\
9871 & (3)\end{array}$ & $\begin{array}{l}0405(1) \\
4418(2) \\
0027(2) \\
6353(2) \\
9873(2)\end{array}$ & 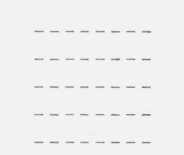 & $\begin{array}{l}3782.0402 \\
3772.4418 \\
3764.0032 \\
3753.6351 \\
3743.9872\end{array}$ & $\begin{array}{l}3780.9663 \\
3771.3703 \\
3762.9345 \\
3752.5685 \\
3742.9231\end{array}$ & $\begin{array}{r}350 \\
1500 \\
1200 \\
3500 \\
1100\end{array}$ & $\begin{array}{l}\text { I } \\
\text { I } \\
\text { I } \\
\text { I }\end{array}$ & II \\
\hline $\begin{array}{l}3728 \\
3720 \\
3712 \\
3702 \\
3693\end{array}$ & $\begin{array}{ll}9626 & (3) \\
4924 & (3) \\
3595 & (2) \\
0310 & (3) \\
6171 & (3)\end{array}$ & $\begin{array}{ll}9622 & (1) \\
4926 & (1) \\
3597 & (2) \\
0313 & (2) \\
6171 & (2)\end{array}$ & 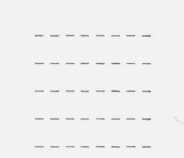 & $\begin{array}{l}3728.9624 \\
3720.4925 \\
3712.3596 \\
3702.0312 \\
3693.6171\end{array}$ & $\begin{array}{l}3727.9022 \\
3719.4345 \\
3711.3037 \\
3700.9780 \\
3692.5661\end{array}$ & $\begin{array}{r}800 \\
3000 \\
600 \\
300 \\
1200\end{array}$ & $\begin{array}{l}\mathrm{I} \\
\mathrm{I} \\
\mathrm{I} \\
\mathrm{I}\end{array}$ & II \\
\hline $\begin{array}{l}3683 \\
3671 \\
3669 \\
3657 \\
3651\end{array}$ & $\begin{array}{l}5343(3) \\
0137(1) \\
1842(3) \\
7352(3) \\
1962(2)\end{array}$ & $\begin{array}{l}5347(2) \\
0141(1) \\
1844(2) \\
7354(2) \\
1971(1)\end{array}$ & 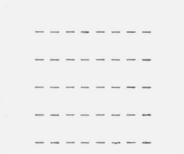 & $\begin{array}{ll}3683 . & 5345 \\
3671 . & 0139 \\
3669 . & 1843 \\
3657 . & 7353 \\
3651 . & 1967\end{array}$ & $\begin{array}{ll}3682 . & 4861 \\
3669 . & 9687 \\
3668 . & 1396 \\
3656 . & 6936 \\
3650 . & 1566\end{array}$ & $\begin{array}{r}1000 \\
750 \\
1000 \\
1000 \\
-\end{array}$ & $\begin{array}{c}\text { I } \\
\text { I } \\
\text { I } \\
\mathrm{I} \\
\mathrm{Hg}^{198}\end{array}$ & \\
\hline $\begin{array}{l}3643 \\
3633 \\
3623 \\
3616 \\
3613\end{array}$ & $\begin{array}{ll}2866 & (3) \\
8656 & (3) \\
8282 & (3) \\
1633 & (1) \\
4575 & (3)\end{array}$ & $\begin{array}{ll}2867 & (2) \\
8654 & (2) \\
8280 & (2) \\
1634 & (1) \\
4573 & (2)\end{array}$ & 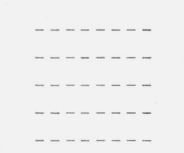 & $\begin{array}{l}3643.2867 \\
3633.8655 \\
3623.8281 \\
3616.1634 \\
3613 . \\
4574\end{array}$ & $\begin{array}{ll}3642 . & 2487 \\
3632 . & 8299 \\
3622 . & 7951 \\
3615 . & 1324 \\
3612 . & 4271\end{array}$ & $\begin{array}{r}2200 \\
1000 \\
800 \\
2000 \\
1400\end{array}$ & $\begin{array}{l}\mathrm{I} \\
\mathrm{I} \\
\mathrm{I} \\
\mathrm{I}\end{array}$ & II \\
\hline $\begin{array}{l}3599 \\
3593 \\
3585 \\
3577 \\
3568\end{array}$ & $\begin{array}{l}1459(3) \\
8040(3) \\
1985(2) \\
5786(3) \\
2818(3)\end{array}$ & $\begin{array}{ll}1464 & (2) \\
8042 & (2) \\
1981 & (2) \\
5782 & (2) \\
2825 & (2)\end{array}$ & 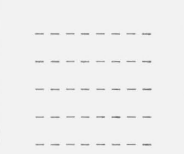 & $\begin{array}{l}\text { 3599. } 1462 \\
3593.8041 \\
3585.1983 \\
3577.5784 \\
3568.2822\end{array}$ & $\begin{array}{l}\text { 3598. } 1196 \\
3592.7788 \\
3584.1753 \\
3576.5573 \\
\text { 3567. } 2635\end{array}$ & $\begin{array}{r}2000 \\
2000 \\
800 \\
1000 \\
1200\end{array}$ & $\begin{array}{l}\text { I } \\
\text { I } \\
\text { I } \\
\text { I }\end{array}$ & II \\
\hline $\begin{array}{l}3560 \\
3552 \\
3545 \\
3540 \\
3519\end{array}$ & $\begin{array}{l}4658(1) \\
4161(3) \\
0306(3) \\
5980(3) \\
4094(3)\end{array}$ & $\begin{array}{l}4657(1) \\
4158(2) \\
0300(2) \\
5983(2) \\
4095(2)\end{array}$ & 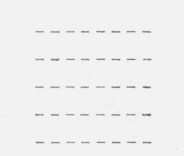 & $\begin{array}{l}3560.4657 \\
3552.4159 \\
3545.0303 \\
3540.5982 \\
3519.4094\end{array}$ & $\begin{array}{l}3559.4490 \\
3551.4013 \\
3544.0176 \\
3539.5867 \\
3518.4033\end{array}$ & $\begin{array}{l}2500 \\
1000 \\
1500 \\
4000 \\
1000\end{array}$ & $\begin{array}{l}\mathrm{I} \\
\mathrm{I} \\
\mathrm{I}\end{array}$ & II \\
\hline $\begin{array}{l}3512 \\
3504 \\
3499 \\
3494 \\
3480\end{array}$ & $\begin{array}{l}1610(3) \\
7880(1) \\
6215(3) \\
5174(2) \\
1680(3)\end{array}$ & $\begin{array}{l}1613(2) \\
7870(1) \\
6216(2) \\
5174(1) \\
1688(1)\end{array}$ & 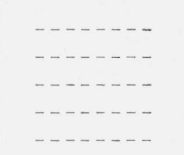 & $\begin{array}{ll}3512 . & 1612 \\
3504 . & 7875 \\
3499 . & 6216 \\
3494 . & 5174 \\
3480 . & 1683\end{array}$ & $\begin{array}{l}3511.1570 \\
3503.7852 \\
3498.6206 \\
3493.5177 \\
3479.1723\end{array}$ & $\begin{array}{r}1000 \\
500 \\
900 \\
2000 \\
800\end{array}$ & $\begin{array}{l}\text { I } \\
\text { I } \\
\text { I }\end{array}$ & $\begin{array}{l}\text { II } \\
\text { II }\end{array}$ \\
\hline $\begin{array}{l}3469 \\
3463 \\
3452 \\
3443 \\
3434\end{array}$ & $\begin{array}{l}2126(3) \\
8419(2) \\
6910(3) \\
5652 \\
9827(3)\end{array}$ & $\begin{array}{ll}2125 & (2) \\
8417 & (2) \\
6908 & (2) \\
5651 & (2) \\
9831 & (2)\end{array}$ & 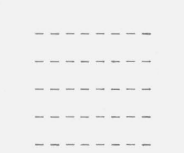 & $\begin{array}{l}3469.2125 \\
3463.8418 \\
3452.6909 \\
3443.5651 \\
3434.9829\end{array}$ & $\begin{array}{l}3468.2193 \\
3462.8500 \\
3451.7019 \\
3442.5785 \\
3433.9985\end{array}$ & $\begin{array}{r}2000 \\
2000 \\
900 \\
800 \\
3000\end{array}$ & $\begin{array}{l}\mathrm{I} \\
\mathrm{I}\end{array}$ & $\begin{array}{l}\text { II } \\
\text { II }\end{array}$ \\
\hline $\begin{array}{l}3422 \\
3413 \\
3406 \\
3397 \\
3393\end{array}$ & $\begin{array}{l}1908(3) \\
9918(3) \\
5346(3) \\
7021(3) \\
0083(1)\end{array}$ & $\begin{array}{ll}1910 & (2) \\
9918 & (2) \\
5348 & (2) \\
7022 & (2) \\
0087 & (1)\end{array}$ & 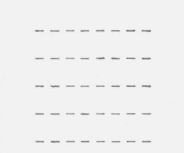 & $\begin{array}{l}3422.1909 \\
3413.9918 \\
3406.5347 \\
3397.7022 \\
3393.0085\end{array}$ & $\begin{array}{l}3421.2097 \\
3413.0127 \\
3405.5575 \\
3396.7273 \\
3392.0348\end{array}$ & $\begin{array}{l}2500 \\
1800 \\
1400 \\
1400 \\
6000\end{array}$ & $\begin{array}{l}\mathrm{I} \\
\mathrm{I} \\
\mathrm{I} \\
\mathrm{I}\end{array}$ & II \\
\hline $\begin{array}{l}3386 \\
3381 \\
3375 \\
3359 \\
3352\end{array}$ & $\begin{array}{l}5033(3) \\
8300(3) \\
9438(3) \\
5663(3) \\
1910(3)\end{array}$ & $\begin{array}{ll}5030 & (2) \\
8305 & (2) \\
9440 & (2) \\
5668 & (3) \\
1913 & (2)\end{array}$ & 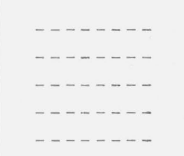 & $\begin{array}{l}3386.5032 \\
3381.8303 \\
3375.9439 \\
3359.5666 \\
3352.1911\end{array}$ & $\begin{array}{l}3385.5312 \\
3380.8595 \\
3374.9746 \\
3358.6014 \\
3351.2278\end{array}$ & $\begin{array}{r}800 \\
900 \\
1600 \\
2000 \\
2500\end{array}$ & $\begin{array}{l}\mathrm{I} \\
\mathrm{I}\end{array}$ & $\begin{array}{l}\text { II } \\
\text { II }\end{array}$ \\
\hline $\begin{array}{l}3338 \\
3331 \\
3326 \\
3325 \\
3310\end{array}$ & $\begin{array}{l}8296(3) \\
4347(2) \\
0765(3) \\
7088(3) \\
3174(3)\end{array}$ & $\begin{array}{l}8297(2) \\
4343(1) \\
0768(2) \\
7088(2) \\
3180(2)\end{array}$ & 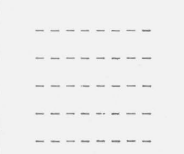 & $\begin{array}{l}\text { 3338. } 8296 \\
3331.4345 \\
3326.0767 \\
3325.7088 \\
3310.3176\end{array}$ & $\begin{array}{l}3337.8697 \\
3330.4765 \\
3325.1201 \\
3324.7523 \\
3309.3650\end{array}$ & $\begin{array}{r}2000 \\
1800 \\
3000 \\
2000 \\
800\end{array}$ & I & $\begin{array}{l}\text { II } \\
\text { II } \\
\text { II }\end{array}$ \\
\hline $\begin{array}{l}3305 \\
3293 \\
3288\end{array}$ & $\begin{array}{l}1894(3) \\
4685(3) \\
7355(3)\end{array}$ & $\begin{array}{l}4686 \quad(1) \\
7357(2)\end{array}$ & - & $\begin{array}{l}\text { 3305. } 1894 \\
3293.4685 \\
3288.7356\end{array}$ & $\begin{array}{l}\text { 3304. } 2381 \\
\text { 3292. } 5202 \\
3287.7885\end{array}$ & $\begin{array}{l}3000 \\
3000 \\
1600\end{array}$ & $\mathrm{I}$ & $\begin{array}{l}\text { II } \\
\text { II }\end{array}$ \\
\hline
\end{tabular}


TABLE 3. Tesl of Thi wavelengths

\begin{tabular}{|c|c|c|c|}
\hline Line pair & Wavelength & Wavenumber & $\begin{array}{l}\text { Wavenumber } \\
\text { difference }\end{array}$ \\
\hline 1 & $\left\{\begin{array}{c}A \\
4494.5941 \\
5160.0411\end{array}\right.$ & $\begin{array}{c}K \\
22248.950 \\
19379.690\end{array}$ & $\begin{array}{c}K \\
2869.260\end{array}$ \\
\hline 2 & $\left\{\begin{array}{l}4375.3536 \\
5003.4922\end{array}\right.$ & $\begin{array}{l}22855.296 \\
19986.041\end{array}$ & 2869.255 \\
\hline 3 & $\left\{\begin{array}{l}3840.7833 \\
4316.4681\end{array}\right.$ & $\begin{array}{l}\text { 26036. } 356 \\
23167.089\end{array}$ & 2869. 267 \\
\hline 4 & $\left\{\begin{array}{l}3643.2867 \\
4068.5993\end{array}\right.$ & $\begin{array}{l}27447.744 \\
24578.483\end{array}$ & 2869. 261 \\
\hline 5 & $\left\{\begin{array}{l}3599.1462 \\
4013.6293\end{array}\right.$ & $\begin{array}{l}27784.367 \\
24915.106\end{array}$ & 2869.261 \\
\hline 6 & $\left\{\begin{array}{l}3331.4345 \\
3683.5345\end{array}\right.$ & $\begin{array}{l}\text { 30017. } 099 \\
27147.838\end{array}$ & 2869.261 \\
\hline 7 & $\left\{\begin{array}{l}3310.3176 \\
3657.7353\end{array}\right.$ & $\begin{array}{l}30208.582 \\
27339.321\end{array}$ & 2869.261 \\
\hline 8 & $\left\{\begin{array}{l}4896.3215 \\
5975.3199\end{array}\right.$ & $\begin{array}{l}20423.495 \\
16735.506\end{array}$ & 3687. 989 \\
\hline 9 & $\left\{\begin{array}{l}3829.4708 \\
4459.2531\end{array}\right.$ & $\begin{array}{l}26113.269 \\
22425.280\end{array}$ & 3687. 989 \\
\hline 10 & $\begin{array}{l}\text { 3305. } 1894 \\
3764.0032\end{array}$ & $\begin{array}{l}\text { 30255. } 452 \\
26567.459\end{array}$ & 3687.993 \\
\hline 11 & $\begin{array}{l}\text { 4896. } 3215 \\
6729.3157\end{array}$ & $\begin{array}{l}20423.495 \\
14860.352\end{array}$ & 5563.143 \\
\hline 12 & $\left\{\begin{array}{l}4258.6944 \\
5580.9077\end{array}\right.$ & $\begin{array}{l}23481.375 \\
17918.232\end{array}$ & 5563.143 \\
\hline 13 & $\left\{\begin{array}{l}4104.4984 \\
5549.7170\end{array}\right.$ & $\begin{array}{l}\text { 24381. } 333 \\
\text { 18018. } 937\end{array}$ & 6362.396 \\
\hline 14 & $\left\{\begin{array}{l}4037.1879 \\
5432.6212\end{array}\right.$ & $\begin{array}{l}24769.716 \\
18407.320\end{array}$ & 6362.396 \\
\hline
\end{tabular}

ards is $10 \mathrm{~A}$ from 3300 to $4300 \mathrm{~A}, 17 \mathrm{~A}$ from 4300 to $5300 \mathrm{~A}, 23 \mathrm{~A}$ from 5300 to $6300 \mathrm{~A}$, and $30 \mathrm{~A}$ from 6300 to $7000 \mathrm{~A}$. This distribution according to wavelength corresponds closely to an average spacing of standards at intervals of $72 \mathrm{~K}$ on a wavenumber scale throughout the range 14300 to $30400 \mathrm{~K}$. Since spectra are always measured in wavelength units, but interpreted in wavenumber units (proportional to energy) this is suggested as the ideal distribution of secondary standards of wavelength. It is emphasized again that the values in table 2 are only a preliminary list which should be refined by comparing still higher orders of interference, and perhaps measuring still more wavelengths to decrease the intervals between standards.
The present list of 222 thorium wavelengths in table 2 may serve for immediate direct measurement of complex spectra from 3300 to $7000 \mathrm{~A}$, and by photographing these standards in a grating's secondorder spectrum and doubling the values, they may serve also for the measurement of spectra from 6600 to 14000 A photographed in the grating's first order.

Finally, the most important next step is to extend the measurement of wavelengths from thoriumhalide lamps to shorter waves, that is from 3300 to $2000 \mathrm{~A}$ or less. When this is done the iron arc at atmospheric pressure may be abandoned as a source of standard wavelengths (except for rough measurements) but still retained as an aid in recognizing the thorium standards. Because of the highly complex character of thorium spectra, and the lack of striking groups of lines or useful maps, it will be convenient (and perhaps necessary) to juxtapose the simpler and more familiar spectrum of the iron are for purposes of orientation.

R. W. Stanley acknowledges the support received from a grant of the National Science Foundation.

\section{References}

[1] R. W. Stanley and W. F. Meggers, J. Research NBS 58, 41 (1957) RP2733.

[2] G. R. Harrison, MIT Wavelength Tables, xv (John Wiley \& Sons, New York, N. Y., 1939).

[3] L. Bovey, Spectrochimica Acta 10, 383 (1958).

[4] M. Fred and F. S. Tomkins, J. Opt. Soc. Am. 47, 1076 (1957).

[5] G. R. Harrison, J. Opt. Soc. Am. 36, 644 (1946).

[6] G. R. Harrison, J. Opt. Soc. Am. 40, 132 (1950).

[7] W. F. Meggers and F. O. Westfall, J. Research NBS 44, 447 (1950) RP2091.

[8] M. Zelikoff, P. H. Wyckoff, L. M. Aschenbrand, and R. S. Loomis, J. Opt. Soc. Am. 42, 818 (1952)

[9] C. H. Corliss, W. R. Bozman, and F. O. Westfall, J. Opt. Soc. Am. 43, 398 (1953).

[10] F. S. Tompkins and M. Fred, J. Opt. Soc. Am. 4\%, 1087 (1957).

[11] W. F. Meggers, Anal. Chem. 28, 616 (1956); Trans. Int. Astron. Union 9, 226 (1957).

[12] W. F. Meggers and K. G. Kessler, J. Opt. Soc. Am. 40, 737 (1950).

[13] K. G. Kessler and W. F. Meggers, J. Opt. Soc. Am. 45, 902 (1955); and unpublished data.

[14] W. F. Meggers and C. J. Humphreys, J. Research NBS 18, 543 (1937) RP992.

[15] B. Edlén, J. Opt. Soc. Am. 43, 339 (1953).

[16] J. R. MeNally, Jr., G. R. Harrison, and H. B. Park, J. Opt. Soc. Am. 32, 334 (1942); ibid. 35, 390 (1945).

[17] Ph. Schuurmans, Physica 12, 589 (1946) (Dissertation, Univ. Amsterdam, 1946).

[18] R. Zalubas (unpublished data, 1957-1958).

Washington, April 22, 1958. 